American Journal of Qualitative Research

June 2020, Vol.4 No. 1, pp. 85-106

https://doi.org/10.29333/ajqr/8267

(C2020 AJQR. http://www.ajqr.org
AMERICAN

JOURNAL OF QUALTATIVE

RESEARCH

ISSN: 2576-2141

\title{
A Meta-study of an Ethnographic Research in a Multicultural and Multilingual Community: Negotiations, Resources, and Dilemmas
}

\author{
Gulbahar H. Beckett ${ }^{1}$ \\ Iowa State University of Science and Technology, USA \\ Masaki Kobayashi \\ Kanda University of International Studies, Japan
}

\begin{abstract}
This yearlong ethnographic project on how a researcher's presence shaped and was shaped by the research context responds to increasing calls for studies of collaborative research on the complex process of gaining entry to research site and maintaining research relationship. Analysis of 70 research journals, audio- and video-recording (interviews and class activities), nine excerpts from student exams, and interviews of 16 students and research assistants in two undergraduate credit courses for Japanese exchange students indicate that conducting a successful ethnographic research study in a multicultural and multilingual setting is a potentially complex process that requires continuous negotiation and renegotiation of relationships, roles, and identities. It is a process that affords potential resources and fraught with dilemmas involving research, same-L1 students, and English-only Discourse in a multilingual community. Findings of the study should benefit researchers communities, particularly graduate students, in their understanding of the principles and procedures of successful collaboration of researchers with teachers, students, teaching assistants, and administrators.
\end{abstract}

KEYWORDS: Collaboration and Reflexivity, Ecological Perspective, Ethnographic Research, Meta-study, Multicultural and Multilingual Community.

\section{Introduction}

Over the last two decades, a growing number of researchers and educators have called for collaborative research in education in general (Goodson, 2000) and in language education in particular (Burns, 1997; Duff \& Early, 1996; Oprandy, 1999; Pappas, 1999; Samuda \& Bygate, 2008). Samuda and Bygate (2008) propose what they call "teacher-driven and research supported inquiry" (p. 262). In this approach, teachers play a pivotal role because it is their pedagogical concerns that drive the inquiry; researchers, on the other hand, "carry out an enabling role in providing terms for focusing the research, in shaping the content and design, and in carrying out the analysis" (p. 262). According to Oprandy (1999), collaborative investigation can exclude the evaluative-component of observations characteristic of the usual top-down, hierarchical,

\footnotetext{
${ }^{1}$ Corresponding author; Professor, Department of English, E-mail :beckett@iastate.edu
} 
supervisory model (p. 151); it can also help build a professional learning community (Burns, 1997; Oprandy, 1999). Underlying this approach is the premise that power must be shared and both teacher and researcher must benefit from the activity (Woods 1995). Thus, status difference becomes one of the challenges faced by professionals who are interested in doing such research (Edelsky \& Boyd, 1993). In fact, Pappas (1999) argues that to develop a collaborative partnership, traditional relationships regarding power/knowledge between teacher-researchers in school and university researchers must be examined and changed.

However, studies to date have been limited to practitioner research collaboration between university researchers and school teachers who may not have had research training. We are not aware of studies that investigated how researchers and researcher-teachers (i.e., teachers who are also well-trained researchers with advanced degrees) collaborate to conduct meta-studies on studies that are being conducted in the teachers' classes. Ellis (2012) distinguishes between formal research and practitioner research. The former refers to "research that is done by an external researcher drawing on one or more of the established traditions" (p. 21) whereas the latter refers to research conducted by teachers as internal researchers in their own classrooms by employing the principles of professional development work such as action research and exploratory practice. The study reported in this article, however, does not fall into either of these categories, and is thus a third type of research that needs attention. Moreover, we do not know what roles and identities are constructed and/or co-constructed among relevant parties such as host teachers (teachers who host researchers in their classes), researchers, students, and teaching assistants as a result of a researcher presence in their classes and program. Nor do we know how these newly co-constructed roles and identities affect the research process. Van Lier (1996) calls for collaborative research by stating that an interesting possibility is collaborative research in which the researcher as an outsider and the teacher as an insider/internal researcher work together; "whether such research can break the barriers between insider and outsider research is itself a useful research topic" (emphasis original, van Lier, 1996, p. 27).

The purpose of this article therefore is to report a meta-study in which two researchers-internal and external--worked together to examine the complex process of doing ethnographic classroom research in a multicultural and multilingual setting. We use the term culture in the article to refer to the practice(s) of research, teaching, learning, and administration. In what follows, we discuss the theoretical framework of the study. We then describe our research methodology, including the setting, participants, and methods for data collection and analysis. This is followed by a presentation of the findings on (1) continual negotiation and re-negotiation the external researcher went through during his study; (2) constructions of various roles and identities and their perceived contributions, and (3) dilemmas that the external researcher faced in conducting his ethnographic research in a multicultural and multilingual setting. Finally, we will discuss the implications of the findings and the importance of the kind of collaborative investigation we report in this article. Here, the term role ${ }^{2}$ is used to refer to an expected behavioral pattern associated with a particular position in a social group whereas the term (social) identity is used to refer to an individual's sense of "who he or she is and how he or she relates to others, based on one's membership in and identification with groups" (Ehrman \& Dörnyei, 1998, p. 67).

\footnotetext{
${ }^{2}$ Wenger (1998) distinguishes roles and identities, saying: "One can design roles, but one cannot design the identities that will be constructed through these roles" (p. 229).
} 


\section{Theoretical Framework}

In this article, we draw upon the work of scholars such as Gee (1996), Harré (1993), Norton (2000, 2013), and van Lier (2000, 2004). As social constructivism ${ }^{3}$ suggests, individuals actively construct their unique understanding drawing on their prior knowledge and interacting with others in a sociocultural context (Halpern, 2017; Spivey, 1997). In other words, this perspective holds that the construction of knowledge never occurs in isolation and that we need to recognize the importance of the environment in which learning occurs (e.g., van Lier, 2004). Of particular relevance here is Gibson's (1979) concept of affordance, which is defined by van Lier (2000) "as a particular property of the environment that is relevant--for good or for ill--to an active, perceiving organism in that environment" (p. 252). This suggests that different individuals, as active agents situated in an environment, perceive, act upon, interact with, and learn different properties of that environment, thus pointing to the importance of paying attention to multiple perceptions in a research context.

Also relevant to the present study is the critical linguistics notion of discourse (McKay \& Wong, 1996; Norton, 2000, 2013). According to Norton (2000), discourses are seen in critical discourse research as "complexes of signs and practices that organize social existence and social reproduction" (p. 14). Such discourses, Norton goes on to say, "delimit the range of possible practices under their authority and organize how these practices are realized in time and space. As such, a discourse is a particular way of organizing meaning-making processes" (p. 14). In a similar vein, Gee (1996) distinguishes Discourse (with a capital D) from discourse (with a small d), saying that whereas the latter refers to language in context, the former refers to "ways of behaving, interacting, valuing, thinking, believing, speaking, and often reading and writing that are accepted as instantiations of particular roles (or 'types of people') by specific groups of people" (p. viii, italics original). From such a perspective, McKay and Wong (1996) identified multiple discourses to which their teenaged, Chinese-immigrant participants were subjected, but of which they were agents, revealing the dynamic interactions between agency and the learning environment. Gee (1996) argues that each individual belongs to multiple Discourses that are often inconsistent and conflicting, which suggests that individuals may come up against dilemmas and struggle as they act out various Discourses. In the present article, we follow Gee's distinction to avoid confusion.

This line of work is not incompatible with the ecological perspective discussed earlier. In fact, with respect to Norton's $(2000,2013)$ theory of social identity, van Lier (1997) states that although not all the scholars he refers to in his article explicitly situate their work in an ecological framework, he would argue that "it is ecological in its focus on contextual analysis, its close attention to the actions of persons in the context, and the search for "patterns that connect"' (Bateson, 1979, p. 16, as cited in van Lier, 1997, pp. 784-785). This becomes even clearer when we further consider the notion of affordance. As van Lier (2000) puts it, "What becomes an affordance depends on what the organism does, what it wants, and what is useful for it" (p. 252). To put it another way, what becomes an affordance relates to who you are, what you are, and what you desire and invest in as active agents (Norton Peirce, 1995). Similarly, McKay and Wong's (1996) study can be considered to be ecological as it draws on Norton' theory and pays close attention to the social and cultural contexts that both shape and are shaped by students' personal agency. In other words, these researchers examined affordances or learning opportunities that L2

\footnotetext{
${ }^{3}$ Although some researchers distinguish constructivism and constructionism (Gergen, 1999), like Spivey (1997), we use the former term to refer to the various constructivist orientations across fields.
} 
students' academic environment provided for them as active, perceiving organisms (van Lier, 2004).

\section{The Qualitative Researcher: An Active Agent in a New Social Environment}

So far, we have limited our discussion of the ecological framework to the studies of second language (L2) learning. In other words, our focus was upon research participants and the environment in which they were situated. Here we would like to shift our attention to the researcher, more specifically qualitative researchers using ethnographic methods. Qualitative researchers, using participant observation, typically spend a considerable amount of time with their participants in the field over a relatively long period of time. This prolonged engagement (Lincoln \& Guba, 1985 ) is deemed to be a vital strategy given that the goal of a naturalistic study is to yield a rich description of the phenomenon under investigation informed by the participants' emic perspectives as well as the researcher's etic perspective. Thus, in such studies, the researchers are always part of the ecology of their research sites, from the beginning when their participants are not accustomed to their presence in the field, to the end when the same participants are more accustomed to the researcher's presence and may even see them as legitimate members of their community. Given the emphasis on participants' emic perspectives, the researchers need to learn to participate appropriately in their "communities of practice" (Lave \& Wenger, 1991). Such participation would entail "maintenance of relationships with participants in temporal and spatial terms" (Sarangi, 2005, p. 376). Furthermore, as Rossman and Rallis (2016) put it, "research should be about learning" (p. X), which in turn suggests that researchers are learners trying to construct "deeper understandings (knowledge) about their topics, the participants, the research process and themselves as inquirers" (p. X1). In short, we regard researchers as social agents acting intentionally according to local norms to achieve their research goals (Harré, 1993).

In qualitative research, the researcher is often described as a primary instrument of research (e.g., Maxwell, 2013; Merriam \& Tisdell, 2015; for want of a better term). In other words, the relationship researchers creates with their participants mediates their research process and outcome. This process of creating a research relationship is often conceived as gaining access/entry. However, Maxwell (2013) argues that such a conceptualization is misleading, saying:

such phrases may lead you to think that this is something that, once, achieved, requires no further orientation. The process of negotiating a relationship is much more complex than these phrases suggest; not only does it typically require ongoing negotiation and renegotiation of your relationships with those you study, but it rarely involves any approximation to total access. (p. 90)

Maxwell goes to argue that what is essential for successful completion of a qualitative study is "relationships that allow you to ethically gain the information that can answer your research questions" (p. 90). This view meshes with van Lier's (2004) ecological perspective discussed above which treats "language as relations between people and the worlds," and learning "as ways of relating more effectively to people and the world" (p. 4). Moreover, considering themselves as an integral part of the research context requires researchers to engage in a process of reflexivity. According to Berger (2015), this terms refers to "the process of a continual internal dialogue and critical self-evaluation of researchers' positionality as well as active acknowledgement and explicit recognition that this position may affect the research process and outcome" (p. 220). The present study therefore takes an ecological approach to examine how an external researcher's actions 
mediated and was mediated by those of an internal researcher who also was the teacher of the classroom in which the former's ethnographic study was conducted.

\section{The Present Study}

The purposes of this meta-study were to examine what contributes to the success of an ethnographic research and how a researcher's presence shape and be shaped by the academic context in which it was conducted. This was done by two researchers - external and internalworking together to examine the process of ethnographic classroom research conducted in a content-based English-as-a-Second-Language (ESL) program at a Canadian university. More specifically, the meta-study was conducted on an ethnographic case study being conducted by Naoki on undergraduate students' learning of academic English language as well as academic content and cultural knowledge in Yultuz's classes and program. We called Naoki the external researcher because he was an outsider (researcher only) to the research site. We called Yultuz the internal researcher because she was the host teacher for Naoki's research and the co-researcher for the present study, which addressed the following questions:

1. What does it take for ethnographic research to be successful in a multicultural and multilingual community?

2. What roles and identities are negotiated at the research site? How do the newly coconstructed roles and identities shape the ecology of the community called the research site?

3. How do the newly co-constructed roles and identities affect the research process?

\section{Methodology}

\section{Research Site, Participants, and Data Collection}

This study was conducted between September, 2000 and May, 2001 in a content-based ESL program at a research university in Canada. The specific contexts of the research were undergraduate credit courses for a group of Japanese exchange students, called Intercultural Communication (September to December, 2000) and Introduction to Research in Social Sciences and Education (January to April, 2001).

The participants in the study included a university lecturer (hereafter Yultuz ${ }^{4}$ ) with advanced degrees in teaching English to speakers of other languages (TESOL), a Japanese ESL doctoral candidate (hereafter Naoki), Yultuz's teaching assistant (hereafter Ben), and 16 undergraduate Japanese university students (see Table 1). All the participants were bilingual or multilingual although they varied in proficiency. For example, Yultuz spoke Uighur as her first language (L1), Mandarin Chinese as her L2, and English as her third language (L3). Naoki spoke Japanese as his L1 and English as his L2. Ben spoke French as his L1, English as L2, and Japanese as his L3. At the time of data collection, Ben was a master's student working on his thesis. All the student participants spoke Japanese as their L1 and English as their L2 and most of them were second-year university exchange students from Japan. Here, it should be mentioned that as an experienced teacher and researcher, Yultuz agreed to let Naoki conduct his doctoral study in her classes mainly out of her strong desire to contribute to the fields of TESOL and applied linguistics research.

\footnotetext{
${ }^{4}$ All names used are pseudonyms.
} 
Yultuz and Naoki conducted the present study on Naoki's doctoral study being conducted in Yultuz's classes and program. As such, Yultuz and Naoki were co-investigators as well as participants. In other words, the present study can be considered as a collaborative, meta-study on the contexts surrounding the ethnographic study that Naoki was conducting in Yultuz's classes.

Table 1

\section{Participants}

\begin{tabular}{llll}
\hline Participants & $\mathrm{N}=19$ & Gender & L1 \\
\hline University ESL students & 16 & $\mathrm{~F}(12) \mathrm{M}(4)$ & Japanese \\
Teacher (Yultuz) & 1 & $\mathrm{~F}$ & Uighur \\
Researcher (Naoki) & 1 & $\mathrm{M}$ & Japanese \\
Teaching assistant (Ben) & 1 & $\mathrm{M}$ & French \\
\hline
\end{tabular}

Data collection reflected a qualitative approach (McMillan \& Schumacher, 1993) and included multiple methods (see Table 2). Specifically, the participants were audio-recorded and observed during their educational activities in natural contexts such as classrooms and computer labs. During his observations, Naoki would note all the instances where Yultuz referred to him or his research. The two co-researchers (Yultuz and Naoki) kept their research journals regarding this study. After observing classes, Naoki would look at his fieldnotes and transcribe relevant classroom discourse that he noted during his observation. This way, the researchers' journal entries were supplemented by transcriptions of classroom discourse (See Appendix for the conventions). Furthermore, fifteen of the student participants, including six key participants for the doctoral study, were interviewed in focus groups; one student e-mailed her response to the research questions. The teaching assistant (Ben) was interviewed individually. With participants' permission, the focus group student interviews were audio- and video-recorded. The individual interview with teaching assistant was audio-recorded.

Table 2

Data Source

Observation

Research Journals

(supplemented by transcripts)

Focus Group Interviews

E-Mail Interview

Excerpts from student exams
Sept. 2000 - April 2001

70 (34 entries by Yultuz from Jun. 26, 2000 to April 17, 2001)

36 entries by Naoki from Aug. 24, 2000 to April 15, 2001)

15 students

1 student

9

\section{Data Analyses}

A theme-based analysis strategy (Spradley, 1980) was applied for the data analyses following the "grounded" theory approach advocated by Glaser and Strauss (1967), Strauss (1987), and Strauss and Corbin (1998; Corbin \& Strauss, 2015). That is, we analyzed our data inductively, which allowed us to be open-minded and sensitive to the contexts of the data. Specifically, we reviewed the transcribed interview data line by line, paragraph by paragraph, to establish categories and sub-categories. We, then, looked at our research journal entries for similar themes, and 
categorized and labeled the emerging themes. We also read and reread the data through constant comparison for regular occurring phrases (see, for example, Lincoln \& Guba, 1985). We looked for frequencies of each category. These analyses allowed us to triangulate the findings emerging from the interview data.

Our coding (category labeling) was inferential. That is, in our coding, we looked for "good explanatory exemplars, not for all instances" (Miles \& Huberman, 1994, p, 65). First, we summarized the segments of data. Then we grouped those summaries into a smaller number of subthemes and constructs as suggested by Miles, Huberman, and Saldana (2014).

\section{Findings}

Our analyses of the data showed that a success of an ethnographic study in a multicultural and multilingual research site can require much deliberate negotiation, re-nogotiation among and investment from various parties. Specifically, we found that multiple identities were co-constructed and negotiated on the research site and various parties involved invested greatly in Naoki's research. For example, (a) Naoki's presence at the research site resulted in construction and coconstruction of new roles and identities. Some of the roles and identities jointly constructed and co-constructed for Naoki included a live example for teaching, a friend and a big brother for students, "another TA", "a dictionary", an assistant for the administration; and an ethnographic researcher for himself; and (b) the newly constructed identities were viewed affording resources for teaching, learning, and data gathering at the research site. Our data also indicate that Naoki encountered dilemmas over the use of L1 and L2 as well as the researcher discourse versus the non-researcher discourses during his research. These themes and sub-themes will be illustrated and discussed through excerpts from data in this section of the article.

\section{Continuous Negotiation}

As mentioned above, one finding of the present study suggests that, in order to conduct successful ethnographic research, the researcher needed continual negotiation and renegotiation of his relationship with his participants (Maxwell, 2013) and other parties closely associated with his participants. In Naoki's case, the negotiation for entry started as early as eight months before the actual data collection began. The negotiation took many forms and involved many parties. For example, Naoki started his entry negotiation by getting to know Yultuz who would be teaching some of the potential participants by sitting in her classes; giving guest lectures to her classes; and by befriending the administrators and other teachers in the program that was identified as the potential research site.

Numerous e-mail messages were exchanged and discussions took place among Naoki, his research supervisor, Yultuz, her teaching assistants, and the Program Director at the research site during the eight-months data collection period. All these messages and discussions were related to gaining entry to the research site and maintaining relationships with the relevant parties. For instance, at the beginning of the second term, upon the suggestion of his key student-participants, Naoki decided to video-tape classroom activities, which made it necessary for him not only to renegotiate with the rest of the students, the teacher, TA, and the Director, but also to revise the consent forms and have them approved by the university's human subject committee (e.g., Naoki's journal, January 4 and 6, February 1, 2001).

Naoki's re-negotiation of his relationships on the research site also took place at a more micro-level. In the following excerpt, Ken, one of the key participants in Naoki's study, explains why he thinks Naoki is completing his data collection successfully: 
K: I've known him for long time almost - since the beginning of August. And one thing which is - totally cool about him is that he made uh - such a big - I don't know - a comfortable - relationship almost with everybody. Now it's like almost everybody knows Naoki... and then it's pretty hard to find someone that doesn't know him... Some things that I can think of - are: whenever I email him, showing him my files, or documents uh - uh: to let him uh see my progress of processes - like to uh reach to like final goals of the article. Then - he always like emails back and thank you - you know or I appreciate you (x) always thank you or and to show uh: his appreciation to students. Probably he does that to - some other people too. So those - you know - u:mm kind of efforts, you know. (Interview, April 6)

Later on the same day, Ken commented that Naoki's immediate and never-failing response thanking him for his participation in the study made him feel appreciated and want to cooperate with Naoki. As this comment, coupled with the above excerpt, shows, Naoki continued to negotiate his relationship with people involved, including access to data (asking them to meet with him for interviews, send him their papers and journals, etc.) throughout the yearlong study.

\section{New Roles, New Identities, and Investment}

Analysis of our data shows that the Naoki's (the external researcher's) presence resulted in new roles and identities co-constructed between Yultuz (the internal researcher and the host teacher), students, teaching assistants, and the program administrators. What is interesting is all of these parties viewed the roles and identities as related to investments for their respective purposes. This section of the article illustrates these points.

\section{Discursive co-construction of identity and its contribution.}

A second finding of the study shows a positive identity construction as it relates to the success of Naoki's data collection, Yultuz's teaching, and her students' learning. For example, both Naoki's and Yultuz's journal entries show that numerous instances of positive identity construction were observed and recorded during the academic year. Specifically, by referring to Naoki and his research as examples in class, Yultuz consciously or unconsciously helped construct Naoki as a very good, credible researcher who does important research and presents his findings at international conferences, and an A+ Japanese ESL doctoral student that her students can learn from (e.g., Transcript of class observation, March 9). For example, during her lectures, seminars, and conversations with students, Yultuz was observed to be telling the students that, as researchers, they should learn from and be inspired by Naoki. In addition, Yultuz often used inclusive pronouns and phrases such as "we", "Naoki and I" in her speech, which might have helped construct Naoki as Yultuz's colleague or friend. The following excerpt from Naoki's journal entry illustrates how Yultuz did this.

In explaining the fact that different fields have different languages, she mentioned that "Naoki and I - we understand each other perfectly" because we are in the same field. But we may not understand someone talking about a certain type of psychology although our English is good enough to do anything, because there are terms that we have not learned 
yet." (Transcribed) She also mentioned that she hoped that her students would find out what they wanted to do in the future at graduate school "like Naoki and I did". (January 4)

If Yultuz constructed a positive identity for Naoki, there is evidence from the data that Naoki did the same for Yultuz. For example, Naoki was asked by Yultuz to do a presentation on his research in class in March. Answering a question from a student about the rigor of doing doctoral studies in North America, Naoki said, “... usually people have to - revise their dissertations after the defense - but Yultuz passed with flying colors - like A+ passing” (Transcript, March 9).

We can see from the above excerpts that Yultuz and Naoki constructed each other discursively as credible researchers and also showed Yultuz's students how much they respect each other. In fact, students commented during the focus group interviews conducted on April 15 and during casual conversations that Naoki had with them that they could tell how much Yultuz and Naoki respected each other as researchers and friends. Our data show that such an identity construction contributed positively to Naoki's data collection for his study, Yultuz's teaching, and her students' learning. This was repeatedly mentioned in both Naoki's and Yultuz's journal entries and in the interviews with the students. For example, in her journal entry, Yultuz wrote,

I am also amazed at how well the last term went and how well this term is going. Got my highest SCETS (6.79, 7 being the full score) on student evaluation last term. More amazing is this term. I did spend a lot time planning the course and choosing texts etc., but I haven't been able to focus $100 \%$ of my time on them with all these job interviews, etc. Still the students don't seem to complain. ... This year, students seemed to have understood what "Ph.D." means even if I didn't explain it to them much. Last year, I spent much more energy on the students, but still there were people falling asleep, more people were absent, I don't think anybody understood what a "Ph.D." meant even though I tried to explain it to them. I don't remember anyone calling me doctor. But this year, I see lots of the students addressing me a Dr. on their assignments. Students have been very respectful. I am starting to wonder if Naoki has played some role here by explaining the meaning of Ph.D. and the importance of all these job interviews I was going to and thereby establishing an important identity for me that needs to be respected. (March 20)

Moreover, many students reported that Naoki's presence made them study harder. For instance, at the focus group interview, one student said,

For myself, I studied very hard. Also, Naoki was here in the classroom, so, yeah, I studied harder. I could ask a lot of questions to him about English grammar. He's like a dictionary. We became very friendly, so through the conversation we got a lot of English skills and grammars. (April 15)

These excerpts suggest that the Naoki's presence was perceived to be something positive by his participants, both teachers and students. 


\section{Key participant identity and investment.}

A third finding of the study revealed that seven of the sixteen students, who were also key participants in Naoki's doctoral study, reported that they saw themselves as having a special identity that required increased investment in the research (Norton, 2000). That is, they understood that their key participant role meant additional responsibilities that required time and effort, which they invested over a period of eight months. Specifically, consciousness of their identity and responsibilities might have resulted in more rigorous studying in general and more active participation in class discussions and creative work on the assignments in particular. These students also reported that their identity as key participants led them to invest more effort in fluency and accuracy in speaking English. Interestingly, some non-key student participants perceived being a key participant as a "privilege" because key participants "have better access to Naoki in many different ways" (Midori, Interview, April 15). Likewise, Satomi said, "If Naoki were to make me a key participant, I would know my English ability, how I improved it through this term" (Interview, April, 15). The following are excerpts from the Naoki's journal entries:

Shin [key participant] told me that Midori was surprised to hear that Eiko was one of my key participants because Yultuz doesn't refer to her name as often as [names of three other key students] in using my research as an example in her lectures. Shin also told me that Midori doubted if he really was one of the key participants and asked him if he could "prove" it by showing her his micro-recorder, which all of my key participants have. Seems as though the micro-recorder is serving as a key-participant ID! Interesting! Also, it seems that in her mind, key participants are those who speak a lot in class; in others, more visible ones than Shin and Eiko. (April 13)

... After dinner, Akemi told me that she could have contributed to my study a lot more as a key participant like Ken and Rachel, but she understood that "you needed to balance out the group by having active ones and less active ones". It seemed to me that she was implying that she belonged to the former group. (April 15, 2001)

What makes these excerpts compelling is that the teacher (and perhaps the TA too) appear to have contributed to the construction of what it meant to be a participant by often referring to the study in which her students were participating. In other words, the meaning of being a key participant is socially constructed through classroom discourse. Moreover, the above excerpts suggest that non-key students like Midori and Akemi seem to have thought that people were selected as key participants based on their active class participation and visibility. If that is the case, we wonder if Akemi tried to legitimatize her identity as a non-key-participant by attributing it to what she thought was Naoki's intention to "balance out" the group. Naoki jotted in his field notebook as follows, "Never did I think anyone would see the micro-recorders and their holders this way! I wonder how such perceptions influence students' motivation and participation. It could go either way." (fieldnotes, April 16). In their final interviews conducted in April, all the key participants commented that having opportunities to reflect on their activities through audiojournals and interviews had helped them one way or another. Some said that it helped them see what they understood and what they did not while others said that having someone to listen to them made them want to strive for the better. Coincidentally, Midori worked with one of the key 
participants to make a joint presentation, and was thus observed and interviewed by Naoki. In her interview, she said that she was very happy to get her turn to share her experiences and that she had worked hard for it." These records shed light on the positive effects of being focal students in the study.

\section{Multiple roles and identities of Naoki}

A fourth finding indicated that multiple roles and identities were co-constructed for Naoki. Some of these roles and identities were a live example for teaching, occasional assistant to the teacher and the administration, guest speaker, a colleague and friend of the teacher, a more capable peer, a "consultant", a "friend," and a "big brother" for students, and an ethnographer for himself. This is what Tsuyoshi, a male non-key student, had to say about his relationship with Naoki:

And uh: - after the class, uh some- I think some student uh: asked about about their research, to Naoki, for example, how can - how could we portfolio, or some kind of consultant, to him, with him? And it was also good for us. I know - of course Yultuz can do it, but uh sometimes, there is $a$ - even we-we are the same- how-what to say. Status or position, like (xx) - but still some - what to say - teachers and students, same relationship. But the - he's not teacher, he's just- he's a researcher, and observer? And the more - how to say - closer, like a friend, he - his behavior, it seems like friends for us? To - more like friend. Yeah. Compared to the teacher. Of course, ((referring to Yultuz)) you are very friendly. ((Everyone laughs)) Just thinking about the researcher and the teacher, I think there's some difference. (Interview, April 15)

This seems to be a compelling comment showing the close relationship that Naoki had with his student participants. Furthermore, both Naoki's and Yultuz's journal entries showed that Naoki had a role as an assistant to the teacher and the administration on various occasions. As an assistant to the teacher, Naoki helped solve computer problems, read student journals with students' permission (this was done because the teacher thought it would be useful for Naoki in his data collection), and helped organize a group of Yultuz's students to give an academic presentation at a local conference. His assistance with the presentation included writing a proposal, preparing for the presentation, and giving the presentation as a co-author. All these roles are evidenced by Naoki's journal entries. For example, in his journal, Naoki writes,

Today, students did some writing on the computer. Yultuz called me, asking me to help a couple of students use Mac computers. After that, more students asked for my help. My first role as a participant observation in Yultuz's class was a computer assistant! (Septembr 14)

As a colleague and friend, Naoki shared pride in students' performance with Yultuz. This can be seen from the following excerpt from Naoki's journal entry.

After Tomomi and Futaba's presentation, Yultuz said to the class, "Naoki and I just were smiling because you have cute and nice use of English. We were very proud how good your English is." (November 23) 
Multiple roles that Naoki played as a researcher in the field were not confined to Yultuz's classes. Upon a request made by the Head Teacher in the program, Naoki conducted eight lunchhour workshops on cross-cultural communication. As a guest speaker and a more capable peer, Naoki was asked by the teacher to give presentations in classes and shared his work with the students as an example. Additionally, Naoki was asked by class representatives and a student adviser to video-tape the graduation ceremony in April. Although Naoki played multiple roles in the field, he did not choose to play all the roles presented by the environment.

Before Class I's lecture started Yultuz asked me if I could do a model presentation for her students. I told her that maybe I shouldn't since I'm looking at oral presentations as a unit of analysis. She agreed and said that she would probably ask Ben. It's great to work with Yultuz because she completely understands my position! (Naoki's journal, October 13)

In this case, Yultuz and Naoki negotiated his role and identity in the classroom. Hearing Naoki's reservation about doing a "model" presentation, Yultuz agreed that she would ask her teaching assistant (TA) instead, respecting Naoki’s position as a researcher.

\section{Resource for teaching.}

Naoki often became a resource for teaching (e.g., a live example in teaching during class discussions). According to his journal entry, Yultuz used his study as an example in explaining the importance and complexity of reporting research findings. She said,

If he's just sitting here ... he's wasting his time and everybody else's time. What he really - should do and will do is - he has to tell us what he found by sitting here for ten months. And ... the whole research field that he's in - people have to know - what did you do for these five years ((referring to years needed for completing a PhD)). (Naoki's journal, January 4)

In her lectures, Yultuz also used Naoki as an example when she needed to explain how doing research would help students develop problem-solving skills. She said that Naoki and she knew that there are a lot of problems that they might encounter in doing research, starting from talking to a teacher. She then explained how Naoki dealt with the problem of memory. She said,

He's not going to remember everything we said here. But with recording, there are things that he cannot tell just by listening to his recording. The solution could have been and we couldn't do that for a lot of reasons that you don't know. The solution could have been video-recording. (class lecture, April 4)

Yultuz then explained how doing research helps students develop cooperative work skills, again by taking Naoki as an example. She told the class that Naoki had to cooperate with her, the students, the other teachers and the administrators in the program. She said,

If he doesn't know how to cooperate with these people - if he makes any one of us angry - he's out. We'll tell him that he cannot do research here. (class lecture, January 4, 2001) 
On another occasion, Yultuz referred to Naoki's study when explaining the term "qualitative" in explaining what she meant by "choice of research methods" as a component of a portfolio. According to Naoki's journal entry, Yultuz told her students that:

You can choose two or three (methods) to do research. Like, for example, Naoki has at least three methods that we can tell immediately, observation, interviews, discourse analysis. (Naoki 's journal \& Transcript, January 5)

Moreover, our interview data show that many students perceived Naoki's presence as facilitative of their teacher's lectures. For example, the following are students' answers to the question, "What are some of the things that you think may have affected your learning - and your teacher's and your TA's teaching, uh: because of Naoki's presence in your class?"

Akemi: I think, definitely, cut the time, to show the good example. Usually, if Naoki was not there you have to say, good researcher has to be like this, like this, like this, right? But you could say that, like Naoki. ((laughs)) ... Seeing is believing. ((several turns later $)$ ) Ken: Uh: So Naoki is worth like uh - I don't know - hundred or two hundred sentences in the - textbook. (Interview, April 15)

What these comments suggest is that the students thought that the teacher was able to save some time explaining what was written in the textbook by referring to what Naoki was doing in her classes. Such examples continued throughout the term in Yultuz's classes. Apparently, Naoki's presence in the field served the teacher and students as something they could build their discussion on.

\section{Resource for students' learning.}

If Yultuz made use of Naoki's presence as a live example for her teaching, her students' seemed to have made use of his presence for learning. For example, in response to an exam question, "What are some of the characteristics of a good researcher?" two students wrote,

One of the characteristics of a good researcher is obedience to the rule. For example, researcher should not plagiarize other researchers' thoughts. ... As another example, researcher should get permission of people who are used for the date of research. For example, Mr. Naoki gave us the paper [consent forms] which ask he can do research us or not. It's important point to observe.

A good researcher should use at least 3 methods when he/she research a case to prove his results and show people that the results have less bias. ... For example, when Naoki shows a fact happened in the classroom, he proves it by not only observation, but also interview with students, who are actually in the class. 
As these comments suggest, students seemed to have benefited from observation of Naoki's research practice in their classrooms. Moreover, that Naoki's presence in a class became a resource for learning was also mentioned at the focus group interview. For example, Tsuyoshi commented:

as she [another student] told, it is very good for us. And we can recognize uh - of course, we are learning research, right? In our class? And there he [Naoki] actually doing research. And uh-for exam-and sometimes you and Naoki have a conversation about the-how-the metho-method of the research, and uh I think the - and uh Naoki could add some comment, uh: against the your - what you said. And you remind something, oh and uh you - you could explain to - about it to the class. and uh that kind of thing, it's umm - for me, it's - it was very nice. (Interview, April 15)

As this comment shows, Yultuz sometimes invited Naoki to participate in her lectures, and Naoki shared his knowledge about and experience in research with the class as a more experienced peer. This participation seemed to be appreciated by many of Yultuz's students.

\section{The Researcher in a Dilemma}

A fifth finding of the present study shows that Naoki encountered dilemmas over the use of L1/L2 in the field (see Mehra, 2001 for a similar dilemma). This seemed to have to do with the possibly conflicting nature of the multiple Discourses (Gee, 1996) that co-existed in the program in which the doctoral study was conducted: namely, 1) the Discourse of ethnographic research practice (i.e., the need to be responsive to participants' preferences), which is endorsed by the classroom teacher and her teaching assistant as well as Naoki himself; 2) Discourse of same-L1 students (e.g., their preference for L1 use with other Japanese people out of class; 3) Discourse of appreciation for diversity and respect for choice (endorsed by the teacher and her TA); and 4) English-only Discourse (endorsed by other teachers on the research site). In this section, we elaborate on these dilemmas through excerpts from the data.

\section{Multiple discourses of same-L1 students, English-only policy, and multilingual researcher and teachers.}

Our observations show that most students in the undergraduate program communicated with each other primarily in their L1 outside the classroom. Here, it is useful to remind the readers that Naoki and the students share their first language and culture (i.e., Japanese). As our interview data show, many students saw him as a big brother, counselor, and friend. As such, it was inevitable that students spoke to Naoki in their shared language, Japanese, outside class, when non-Japanese speakers were not around. For example, some students shared with Naoki their thoughts about the topics of their classes. Other students chatted with Naoki, expressing their appreciation for his assistance in their learning about life in Canada ${ }^{5}$. As these conversations often took place after classes, Naoki respected the students' choice of L1 use by participating in the conversations in Japanese. As our data (e.g., Naoki's fieldnotes and interview transcripts) show, many students expressed their appreciation for being able to share their thoughts and feelings with Naoki in Japanese.

\footnotetext{
${ }^{5}$ For example, some students called the researcher at home when they were sick or hurt, and asked for information.
} 
Satomi: Talking about the (xxx) you ask, I think Naoki can speak Japanese and we are Japanese. So it seems that uh: he has more ((Ss nod)) benefit to be more=

Tsuyoshi: =It's easier for him to get closer to you.

Satomi: yeah. we also can talk with him in Japanese.

(Interview, April 15)

However, as the following excerpt from Naoki's journal entry shows, his action, taken out of respect for students' choice, met with opposition.

Shortly after that [after Ben dismissed the class], Tom [another teacher] came in apparently to talk to Ben. ... I continued the conversation in Japanese with the students, because I thought I didn't want to defeat the students' interest in the topic and because I thought it would help me get to know the students more... After the third class, which ended around 3:00, Ben and I went to Yultuz's office to have an interview, at which point, Ben told me that Tom was not happy to see me talking to students in Japanese. (October 16)

As he writes in his journal entry, such opposition made little sense to Naoki. He felt that as a researcher doing an ethnographic study, he should respect the students' choice of language. Although Naoki as an ethnographer wanted to be a "good guest" sensitive to the rules of the host community, he thought that not respecting students' choice and choosing to speak to them only in English might create undesirable distance between himself as a researcher and his participants whose perspectives were vital to the study. Naoki writes in his journal,

But do I need to speak to students in English all the time? Even not in class time? As a researcher using ethnographic techniques, I feel that I must be responsive and sensitive to the students' preferences. If they would rather talk to me in Japanese, I think I should accommodate to them. Anyway I need to be more careful. I don't want to jeopardize my study. (October 26)

But at the same time, he was afraid that he might jeopardize his relationship with other teachers in the program by choosing students' preferences over theirs. The following excerpts from Naoki's journal entry show that he was also caught between students' desire to speak to him in Japanese (students' and his L1) and the English-only Discourse of teachers such as Tom and Mary who speak English as their L1. Tom and Mary are teachers in the program where Naoki's research and the present research were conducted.

Ben also told me that Tom said to him, "It's your class. Do something about it." and left without giving him a chance to explain the situation (the class was over and Ben said that he didn't see any problem with our talking in Japanese). I told Ben that I felt sorry that he was caught in that awkward situation and wished that Tom had talked to me directly. (October 16)

During the break, Ken came to me and asked me how I was getting along with Mary. Surprised, I said we were getting along fine and asked him why. He told me that Mary seemed to have complained about me to some dorm 
residents, saying that this year's students speak Japanese much more because I am around. Where does this come from? The only reason I can think of is that Mary saw me talking to Mei in the lab after Ben's class on Wednesday. Mary came in right before Ben dismissed the class...((after the class was over)) I was noting the date and class on one of the cassettes when Mei brought one of the desk-top recorders to me, saying "Here it is Naoki" in Japanese, so I thanked her in Japanese...Not sure how Mary might see this (Although I noticed that the English-only signs had been removed from the walls of the lab before this semester started), I immediately switched back to English and said "That's very nice of you Mei". She uttered a few more words in Japanese but I continued to speak in English. So the only Japanese I used then was "thank you". I have been very careful about my choice of language since the very beginning of the study in August. (January 19)

These excerpts show that the English-as-L1-teachers' policy and Naoki's desire to accommodate to the students appeared to be in conflict. To borrow Guillemin and Gillan's words, they are "ethically important moments" when "difficult, often subtle, and unusually unpredictable situations... arise in the practice of doing research" (p. 262).

As we can see from the following excerpts, the English as L2 ${ }^{6}$ speaker teacher (Yultuz), the teaching assistant, and students seem to be more understanding of the choices Naoki had to make in the field. For example, Naoki wrote in his journal entries,

I called Yultuz after I got home and explained the situation. She said not to worry. She understood why I spoke in Japanese with students. Most importantly, the students wanted to speak Japanese. So she would do the same thing as a researcher. Also, she knew from her own experience as an international student that speaking $L 1$ might be necessary for students to maintain their self-esteem. She said she would talk to Tom if he complained about my talking to students in Japanese. I am still shocked about Tom's reaction but feel lucky to have people like Yultuz and Ben, who understand and support my position. (October 16)

In fact, both Yultuz and Ben, defended their students' preference for L1 use and Naoki's position regarding this matter. On several occasions, they explained to their colleagues who showed concern the possible reasons for students' choice of L1 and Naoki's reason for his use of Japanese with students.

As the following entry from Naoki's journal shows, it was not only the teacher and the teaching assistant that supported him.

Ken told me that he and other students knew very well why I speak Japanese and he even explained it to their residents who were told by Mary that I was the "cause" of the students speaking more Japanese than the previous groups. He felt that I should know what was going on. After the class, I talked to Yultuz about this. She was very supportive and understanding.

\footnotetext{
${ }^{6}$ As mentioned earlier, Yultuz speaks English as a third language. However, we use the term L2 here to refer to languages other than L1.
} 
She told me not to worry. I hope this would not be too big an issue. (January 19)

In short, facing this ethically critical moment, Naoki sought assistance from the instructor and obtained support not only from the teacher, but also from the TA and some of his key participants.

\section{Discussion}

The forgoing analysis yields many interesting challenges that researchers can face, kinds of resource their presence can provide, and some dilemmas that they may encounter during ethnographic studies at multicultural and multilingual research sites. For example, one of our findings suggests that the process of negotiating a research relationship is not a one-time event. Instead, as Maxwell (2013) argues, it is a continuous effort in which researchers need to negotiate and renegotiate their relationships with people involved for successful completion of their research. Our findings seem to indicate that such negotiations can include researchers' ability and willingness to function with multiple roles and identities such as friend, colleague, assistant, big brother, and counselor. Such ability and willingness of external researchers can create possibilities for the kind of collaborative research van Lier (1996) called for.

The findings of our study also show that an external researcher's presence can result in important new roles and identities for various parties (e.g., host teacher, students, teaching assistants, and program administrators) in a new ecology called research site. They can include internal researcher for the host teacher, key and non-key participants for the students, research participant for the teaching assistant, and a researcher, friend, and a colleague for the external researcher. Moreover, our findings reveal that, as active agents (Harré, 1993; Norton, 2000, 2013), the various parties involved in the study invested in the success of the research as well as benefited from affordances provided by the ecology of the collaboration between the two researchers. For example, the internal researcher made use of the external researcher's presence to benefit her teaching. As shown in the previous section, she often referred to the external researcher's study and his research methods as live examples in her teaching. According to one of her journal entries, she even "learned a thing or two" about research techniques from the external researcher. Several students reported on their investment in their learning as key participants (Norton, 2000) as well as on their learning through observation of a live research practice (Lave \& Wenger, 1991; Wilder et al., 2017). For example, they said that by watching Naoki conducting his research over a period of one academic year, the students learned how to take research notes, how to observe, and how to interview participants. Also, they said that they appreciated the chance to reflect on their learning through journaling and interviews because it helped them clarify their understandings. What this suggests is that both interviewing and journaling were form of what Swain (2009) calls languaging - "a process of making meaning and shaping knowledge and experience through language" (p. 98). However, we do not know how the rest of the students felt about not being selected as key participants or not having been invited to face-to-face interviews. As Naoki wrote in his field notebook, these could have worked either positively or negatively. Some students like Akemi might have worked hard to prove themselves while others might have felt that they were not worthy of research attention. Although there are no easy answers or simple solutions, this is an important issue that concerns reflexivity.

It was not only the research participants that benefited, the external researcher, too, benefited from the rich data collection opportunities that the research environment afforded him as he negotiated and renegotiated his relationships with the people involved. Naoki's fieldnotes and 
journal entries show that he benefited from the Yultuz's (teacher's) research expertise as well. Naoki felt that by regularly interacting with a teacher who was also an experienced researcher, he learned much about the students and the research context as well as useful skills to cope with problems of great delicacy such as negotiating relationships on the research site.

Finally, our findings indicated that the Naoki was caught in dilemmas. By accommodating to the students' preference to speak L1 outside the classroom, he faced unexpected opposition from some of the teachers in the program. In other words, he was caught between the Discourse of sameL1 students and the Discourse of English-only policy. This dilemma was mediated by the Discourse of ethnographic research practice and the Discourse of appreciation for diversity and student choice. Our data analysis shows that doing ethnographic research in a multicultural and multilingual community is a complex task. It takes much more than negotiations for initial entry as suggested by the literature on qualitative research methodology (Akojie et al., 2019; Maxwell, 2013; Raza, 2018). Also, in doing ethnographic research in a multicultural and multilingual community, the researchers may face unexpected problems as they need to juggle different, possibly conflicting beliefs and values of multiple Discourses, and therefore requires support from a "village" or the multiple parties involved, for successful completion of data collection. It is important to reiterate that it was the internal researcher who was most instrumental in dealing with the ethically important moment.

In summary, our findings clearly show that Naoki's presence in the content-based ESL classes was perceived positively and became resources for teaching and learning. Unlike the conventional research practice where an external researchers sit in classes, study some students and their teachers, and go off to write their papers, the researcher presence in this study was treated as part of an ecological environment "in which external and internal researchers collaborated" (van Lier, 1996, p. 27), and students, their teaching assistant, administrators, and even Yultuz and Naoki themselves learned many things they could not have learned in a more conventional research context.

\section{Implications}

The present study implies that researcher presence in content-based ESL classes can contribute to the creation of a positive learning environment for many and that researcher teacher collaboration around a study is a vital component. However, we understand that not all collaboration may be as successful as ours. We realize that our findings may address a unique context. For example, the fact that one of the courses being observed by Naoki was itself a research course, Naoki sharing a similar background with the students, Yultuz and Naoki knowing each other before Naoki started his research, and Yultuz's identity as a researcher and investment in research practice--her being a researcher who sees assisting other researchers as her contribution to the research community--may have contributed to the success of the collaboration.

Nevertheless, we believe the findings of our study adds new knowledge to the qualitative research methods as well as the multiple D/discourses literature and confirms existing research on identity and investment issues in second language education. For example, our study provides empirical data that show the complex process of doing ethnographic research discussed in Maxwell (2013). It shows, as active agents (Harré, 1993), what and how ESL teacher, student, and researcher participants may invest in an ethnographic research to achieve their various purposes in a sociocultural context (Norton, 2000; van Lier, 1997, 2000) called the research site. Our finding on researcher dilemmas not only serves as one more example that shows the complexity of qualitative inquiry, but also adds to the discussions about the possible conflicting nature of the multiple Discourses (Gee, 1996; MacKay \& Wong, 1996; Norton, 2000) that may co-exist on research sites. 
We believe these findings of our study make a great contribution to other researchers' and graduate students' further understanding of the issues discussed in this article.

Furthermore, the findings of our study can make a meaningful contribution to classroom teachers' and administrators' understanding of the benefits of a researcher working in their classes and institutions by demonstrating the importance of examining the interactive nature of researchers and research participants, and the environment in which the study is conducted. We could not agree more with Mehra (2001) when she says with respect to the dialectical nature of human research:

If a researcher seeks to understand human experience, he or she must be in a constant, sensitive, and dialogical relationship with other humans. Also, the researcher must be able to deal with conflicts and contradictions that emerge through an interplay of various oppositional forces of the respondents' realities and his or her own reality. Thus, the researcher, in the naturalistic paradigm of inquiry, is not just an observer; he or she both disturbs the research setting and is also disturbed by it. (p. 69)

It is our hope that this study benefits other researchers and graduate students in their understanding of the principles and procedures of successful collaboration of researchers with teachers, students, teaching assistants, and administrators.

\section{Funding Details}

This work is not supported by any grant funding.

\section{Disclosure Statement}

This is to acknowledge that there is no conflict of financial interest or benefit that has arisen from the direct applications of this research.

\section{Biographical Note}

Gulbahar Beckett, Ph.D., is a professor of Applied Linguistics/TESL at Iowa State University of Science and Technology, USA. She has published numerous books and articles including in the Review of Educational Research; Journal of Mixed Method Research; Language Policy; and The Modern Language Journal. Her books include Global perspectives on project-based language learning, teaching, and assessment: Key approaches, technology tools, and frameworks (co-edited with Dr. Tammy Slater) published by Routledge in 2020.

Masaki Kobayashi, Ph.D., is a professor of Educational Linguistics in the Department of English at Kanda University of International Studies, Japan. His research interests include academic discourse socialization, task-based second language research, and second language teacher education. He has published widley on these topics in international journals and edited volumes.

\section{Acknowledgment}

We would like to thank Drs. Bonny Norton, Paul Kei Matsuda, and Suhanthie Motha for their feedback on an earlier version of the article. 


\section{References}

Akojie, P., Entrekin, F., Bacon, D., \& Kanai, T. (2019). Qualitative Meta-Data Analysis: Perceptions and Experiences of Online Doctoral Students. American Journal of Qualitative Research, 3(1), 117-135. https://doi.org/10.29333/ajqr/5814

Bakalar, B. (2017). Understanding the whole student: holistic multicultural education [Book Review]. Journal of Ethnic and Cultural Studies, 4(2), 96-98.

Berger, R. (2013). Now I see it, now I don't: Researchers' position and reflexivity in qualitative research. Qualitative Research, 15, 219-234. doi.10.1177/1468794112468475.

Burns, A. (1997). Collaborative action research for English language teachers. New York: Cambridge University Press.

Corbin, J. \& Strauss, A. (2015). Basics of qualitative research: Techniques and procedures for developing grounded theory (4th ed.). Thousand Oaks, CA: Sage.

Duff, P. (2000). Repetition in foreign language classroom interaction. In J. K. Hall \& L. S. Verplaetse (Eds.), Second and foreign language learning through classroom interaction (pp. 109-138). Mahwah, NJ: Lawrence Erlbaum.

Duff, P., \& Early, M. (1996). Problematics of classroom research across sociocultural contexts. In J. Schachter \& S. Gass (Eds.), Second language classroom research: Issues and opportunities (pp. 1-30). Mahwah, NJ: Lawrence Erlbaum.

Edelsky, C., \& Boyd, C. (1993). Collaborative research: More questions than answers. In S. J. Hudelson \& J. W. Lindfors (Eds.), Delicate balances: Collaborative research in language education (pp. 4-20). Urbana, IL: National Council of Teachers of English.

Ehrman, M. E., \& Dörnyei, Z. (1998). Interpersonal dynamics in second language education: The visible and invisible classroom. Thousand Oaks, CA: Sage.

Ellis, R. (2012). Language teaching research and language pedagogy. Malden, MA: WileyBlackwell.

Gee, J. P. (1996). Social linguistics and literacies: Ideology in discourse (2nd ed.). Bristol, PA: The Falmer Press.

Gergen, K. J. (1999). An invitation to social construction. Thousand Oaks, CA: Sage.

Gibson, J. J. (1979). The ecological to visual perception. Boston, MA: Houghton Mifflin.

Glaser, B.G., \& Strauss, A.L. (1967). The discovery of grounded theory: Strategies for qualitative research. Chicago, IL: Aldine.

Goodson, I. (2000). Professional knowledge and the teacher's life and work. In C. Day, A. Fernandez, T. E. Hauge, \& J. Moller (Eds.), The life and work of teachers: International perspectives in changing time (pp. 12-25). London, England: Falmer Press.

Guillemin, M., \& Gillam, L. (2004). Ethics, reflexivity, and "ethically important moments" in research. Qualitative Inquiry, 10, 261-280. doi.10.1177/1077800403262360.

Halpern, C. (2017). Book Review: In search of understanding: The case for constructivist classrooms. American Journal of Qualitative Research, 1(1), 32-36.

Harré, R. (1993). Social being (2nd ed.). Oxford, England: Blackwell.

Lave, J., \& Wenger, E. (1991). Situated learning: Legitimate peripheral participation. New York, NY: Cambridge University Press.

Lincoln, Y. S., \& Guba, E. G. (1985). Naturalistic inquiry. Newbury Park, CA: Sage.

Maxwell, J. A. (2013). Qualitative research design: An interactive approach (3rd ed.). Thousand, Oaks, CA: Sage. 
McKay, S., \& Wong, S. C. (1996). Multiple discourses, multiple identities: Investment and agency in second-language learning among Chinese adolescent immigrant students. Harvard Educational Review, 66, 577-603. doi:10.17763/haer.66.3.n47r06u264944865.

McMillan, J. H. \& Schumacher, S. (1993). Research in education: A conceptual introduction (3rd ed.). Harper Collins Publishers.

Mehra, B. (2001). Research or personal quest?: Dilemmas in studying my own kind. In B. M. Merchant \& A. I. Willis (Eds.), Multiple and intersecting identities in qualitative research (pp. 69-82). Mahwah, NJ: Lawrence Erlbaum.

Merriam, S. B., \& Tisdell, E. J. (2015). Qualitative research: A guide to design and implementation. San Francisco, CA: Jossey-Bass.

Miles, M. B,, Huberman, A. M., \& Saldana, J. (2014). Qualitative data analysis: A methods source book (3rd ed.). Thousand Oaks, CA: Sage.

Norton, B. (2000). Identity and language learning: Gender, ethnicity and educational change. Harlow, Longman.

Norton, B. (2013). Identity and language learning: Extending the conversation (2nd ed.). Bristol, England: Multilingual Matters.

Oprandy, R. (1999). Teachers talking about teaching collaborative conversations about an elementary ESL class. In J. G. Gebhard \& R. Oprandy (Eds.), Language teaching awareness: A guide to exploring beliefs and practices (pp. 149-171). New York, NY: Cambridge University Press.

Pappas, C. (1999). Becoming literate in the borderlands. In A. Göncü (Ed.), Children's engagement in the world: Sociocultural perspectives (pp. 228-260). New York, NY: Cambridge University Press.

proficiency. In H. Byrnes (Ed.), Advanced second language learning: The contribution of Halliday and Vygotsky (pp. 95-108). New York, NY: Continuum.

Raza, K. (2018). The Muddy Waters of Multicultural Acceptance: A Qualitative Case Study on Antisemitism and the Israeli/Palestinian Conflict. Journal of Ethnic and Cultural Studies, 5(1), 1-15.

Rossman, G. B., \& Rallis, S. F. (2016). An introduction to qualitative research: Learning in the field. Thousand Oaks, CA: Sage.

Samuda, V., \& Bygate, M. (2008). Tasks in second language learning. Basingstoke, England. Palgrave Macmillan.

Sarangi, S. (2005). The conditions and consequences of professional discourse studies. Journal of Applied Linguistics, 2, 371-394. doi: 10.1558/japl.v2i3.371.

Spivey, N. N. (1997). The constructivist metaphor: Reading, writing, and the making of meaning. San Diego, CA: Academic Press.

Spradley, J. (1980). Participant observation. New York, NY: Holt, Rinehart \& Winston.

Strauss, A. L. (1987). Qualitative analysis for social scientists. Cambridge: Cambridge University Press.

Strauss, A. L. \& Corbin, J. (1998). Basics of qualitative research: Grounded theory procedures and techniques (2nd ed.). Newbury Park, CA: Sage.

Swain, M. (2009). 4 Languaging, agency and collaboration in advanced second language proficiency1. Advanced language learning: The contribution of Halliday and Vygotsky, 95.

van Lier, L. (1996). Interaction in the language curriculum: Awareness, autonomy, and authenticity. Harlow, England: Longman.

van Lier, L. (1997). Observation from an ecological perspective. TESOL Quarterly, 31, 783-786. doi: $10.2307 / 3587762$. 
van Lier, L. (2000). From input to affordance: Social-interactive learning from an ecological perspective. In J. P. Lantolf (Ed.), Sociocultural theory and second language learning (pp. 245-259). Oxford, England: Oxford University Press.

van Lier, L. (2004). The ecology and semiotics of language learning: A sociocultural perspective. Boston, MA: Kluwer Academic Publishers.

Wenger, E. (1998). Communities of practice: Learning, meaning, and identity. New York, NY: Cambridge University Press.

Wilder, L. K., Sanon, D., Carter, C., \& Lancellot, M. (2017). Narrative Ethnographies of Diverse Faculty in Higher Education:" Moral" Multiculturalism among Competing Worldviews. Journal of Ethnic and Cultural Studies, 4(2), 1-12.

Woods, P. (1995). Creative teachers in primary schools. Buckingham, England: Open University Press.

\section{Appendix}

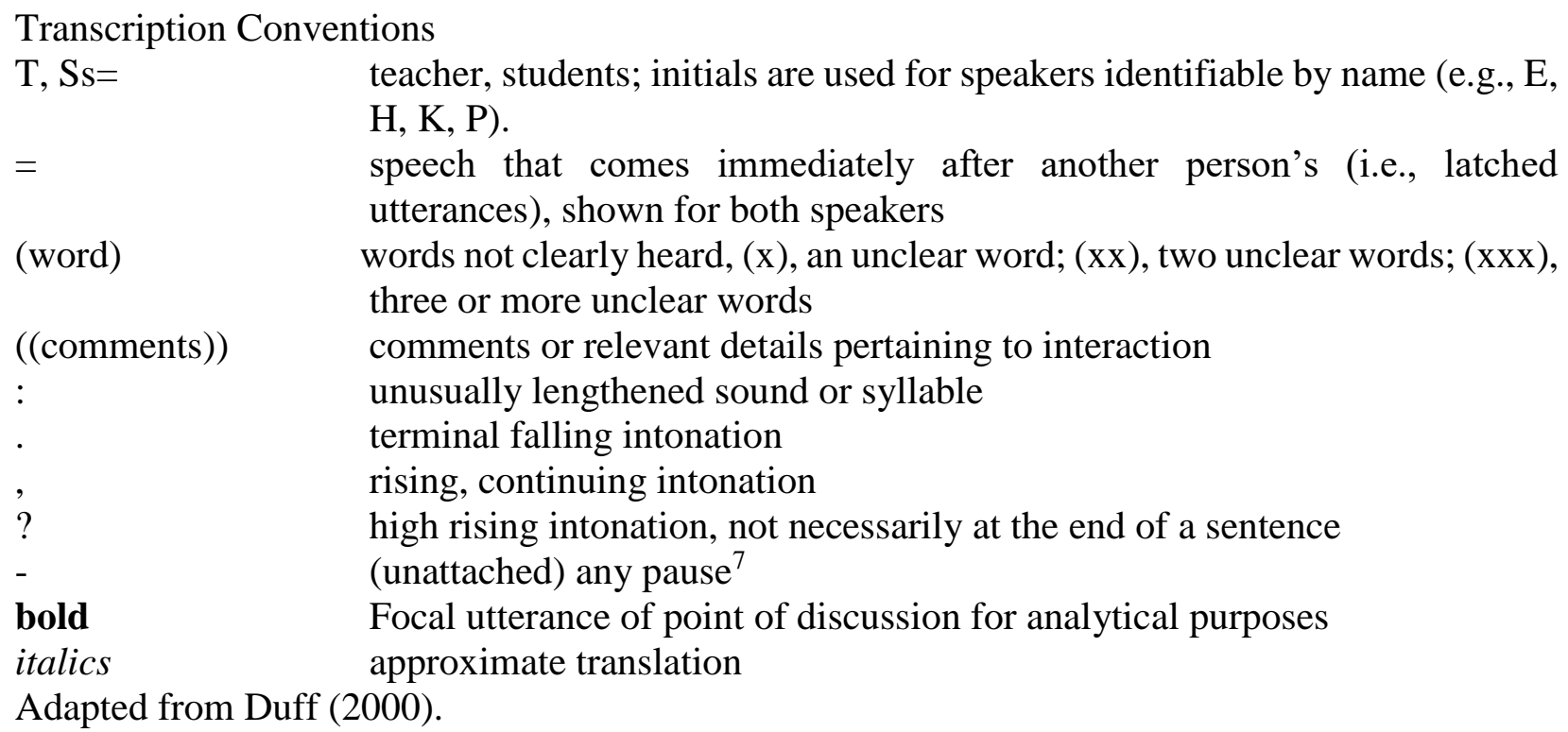

Manuscript received March 12, 2020

Final revision received May 09, 2020

Accepted May 13, 2020

${ }^{7}$ We have not included the exact length of brief pauses in this paper. 